\title{
Assessment of knowledge, attitude and practice about menstruation and menstrual hygiene among secondary high school girls in Ogbomoso, Oyo state, Nigeria
}

\section{Funmito Omolola Fehintola ${ }^{1 *}$, Akintunde Olusegun Fehintola ${ }^{2}$, Ayodele Olatayo Aremu ${ }^{3}$, Ajibola Idowu ${ }^{3}$, Olumuyiwa A Ogunlaja ${ }^{4}$, Idowu Paulina Ogunlaja ${ }^{5}$}

\author{
${ }^{1}$ Department of Community Health, ${ }^{2}$ Department of Obstetrics and Gynecology, Obafemi Awolowo University, Ile-Ife, \\ Osun State, Nigeria \\ ${ }^{3}$ Department of Community Medicine, ${ }^{4}$ Department of Obstetrics and Gynecology, Bowen University Teaching \\ Hospital Ogbomoso, Oyo State, Nigeria \\ ${ }^{5}$ Deaprtment of Obstetrics and Gynecology, General Hospital Ilorin, Kwara State, Nigeria
}

Received: 17 February 2017

Accepted: 24 March 2017

\section{*Correspondence: \\ Dr. Funmito Omolola Fehintola, \\ E-mail: funmitoabioye@yahoo.com}

Copyright: (c) the author(s), publisher and licensee Medip Academy. This is an open-access article distributed under the terms of the Creative Commons Attribution Non-Commercial License, which permits unrestricted non-commercial use, distribution, and reproduction in any medium, provided the original work is properly cited.

\section{ABSTRACT}

Background: Menstruation has more profound effect on quality of education than other aspect of puberty because it involves a learning component as well as elements affected by the school environment and infrastructure. It is, therefore, imperative to assess the knowledge, attitude, and practice of Secondary School girls in Ogbomoso on the subject of menstruation and menstrual hygiene.

Methods: It was a cross-sectional study carried out between June and August 2016. A total of 447 eligible female adolescent secondary school students were selected by multistage sampling technique. A semi-structured facilitated self- administered questionnaire was used.

Results: Majority (96.4\%) of the adolescents have heard about menstruation before menarche while $55.9 \%$ had good knowledge of menstruation and menstrual hygiene. Despite the high level of knowledge, about $64 \%$ of the respondents describe their response to their first menses as scary, discomforting or emotionally disturbing. Also, only $25 \%$ of the respondents had good menstrual hygiene practice. Factors that were significantly associated with good knowledge of menstruation and menstrual hygiene in this study were older adolescent age (15-19 years) $\left(\chi^{2}=47.68\right.$, $\mathrm{P}<0.0001)$; adolescents whose mothers have greater than secondary school education $\left(\chi^{2}=42.52, \mathrm{P}<0.0001\right)$; and those living with their parents $\left(\chi^{2}=123.9, \mathrm{P}=0.001\right)$ while only living with parents significantly influenced good practices.

Conclusions: The study concluded that majority of the adolescents do not observe good hygienic practice during menstruation despite relatively good knowledge of menstruation and menstrual hygiene. Efforts have to be put into ensuring that adolescents are well educated on the meaning of menstruation, the importance of good hygienic practice both in schools and at home.

Keywords: Assessment, Knowledge, Menstrual hygiene, Practice

\section{INTRODUCTION}

Menstrual hygiene is a problem for adolescent girls in developing countries, particularly when attending schools. ${ }^{1}$ Until now, poor menstrual hygiene in developing countries has been an insufficiently acknowledged problem. ${ }^{1}$ In several cultures, there are (cultural and or religious) taboos concerning blood, 
menstruating girls and women. ${ }^{2}$ Menstruation is a particularly salient issue because it has a more pronounced effect on the quality and enjoyment of education than do other aspects of puberty. It involves a learning component as well as elements affected by the school environment and infrastructure. ${ }^{3}$ These include access to menstrual hygiene materials, latrines and places to change, safe water and sanitation, and good hygiene practices like hand washing with soap. Without these, the school environment is unhealthy, gender discriminatory and inadequate. ${ }^{3}$ For girls, puberty means the onset of menstruation. In many contexts, menstruation is considered a private issue, making it difficult to speak about it in public, for instance in a classroom. Many girls are not properly prepared.

Numerous studies, particularly from low-income countries, show that a very high number of girls start menstruating without having any idea what is happening to them or why. ${ }^{4-6}$ Since parents can find it difficult to speak of sensitive and sexual issues with their children, even while admitting it is also their responsibility.,8 Menstrual hygiene is also likely to be affected by contextual factors, such as access to places where girls can manage menstruation-related washing in privacy and comfort. These factors are influenced by having access to water, hygiene and sanitation facilities at school or household..$^{9,10}$ Poor MHM may increase a woman's susceptibility to reproductive tract infections (RTI). ${ }^{11}$ Reproductive tract infections, which have become a silent epidemic that devastates women's lives is closely related to poor menstrual hygiene. ${ }^{12,2}$

Studies in Africa have found out the use of sanitary pads as low as $18 \%$ amongst Tanzanian women with the remainder using cloth or toilet paper. ${ }^{13}$ Studies of Nigerian schoolgirls have found between 31 and $56 \%$ using toilet tissue or cloth to absorb their menstrual blood as opposed to menstrual pads..$^{9,14}$

A study conducted in Ethiopia showed that, though most (92\%) students were aware of menstruation before menarche, their utilization of sanitary napkins was low at $37.6 \%$ and a significant proportion, $62.4 \%$ were using rags and pieces of cloth. ${ }^{15}$ Eleven percent of girls in Ethiopia change their menstrual cloths once a day. ${ }^{16}$

Most girls in Ethiopia are at risk of getting genitourinary tract infections due to their unhygienic practices during their menstruation period which may lead to further complication if left untreated. ${ }^{17}$

Public health experts, health educators and policy makers who work with adolescents need up to date information on knowledge, attitudes, and practices of menstrual hygiene so as to help shape policies and programs on improving adolescence reproductive health.

On this backdrop, this study was conducted to assess the knowledge, attitude, and practices associated with menstruation and menstrual hygiene among in-school adolescent in Ogbomoso, Oyo state Nigeria.

\section{METHODS}

\section{Study location}

This cross-sectional study was conducted among students in selected public schools in Ogbomoso North Local Government Area (LGA) of Oyo State, southwest Nigeria. The 2006 National Population and Housing Census reported a population of 170,858 for the local government. The LGA has about ten public secondary schools most of which are sub-divided into many arms for ease of administration. ${ }^{18}$ The sample size was determined using Fisher's formula. ${ }^{19}$

A total of 447 respondents were selected for the study using multi-stage sampling method. Students who gave their consent to participate in the study and whose school authority gave us permission were recruited into the study. Students with significant physical or mental handicap, which could affect their ability to respond validly to the study instrument, were excluded from the study.

The multi-stage sampling method was used to select eligible respondents over a period of three months. In the first stage, four public secondary schools were selected by balloting from the list of ten government secondary schools within Ogbomoso North LGA. The number of respondents per school was proportionate to their population sizes. In schools with more than one arm, one arm of the school was selected by balloting. Stage two involved selection of eligible respondents from the classes of the selected schools.

The selection at this stage was equally proportional to class sizes. At the final stage, systematic sampling method was used in selecting students from selected classes. Sampling interval was calculated by dividing the total number of students to be recruited from the school by the total number allotted to a class. The first participant was selected using simple random method (by balloting). Students in Senior Secondary three (SS3) did not participate in the study due to their final examination that was ongoing during the time of the survey.

\section{Data collection method and instrument}

Data were collected using facilitated self-administered questionnaire with several questions adapted from previous studies. $^{20,21}$

The questionnaire was translated from English to Yoruba through a two-way process for students who may find the instrument easier to complete in the local language. Questions were asked about respondents' sociodemographic characteristics as well as their, knowledge, attitude and practice on menstruation and menstrual 
hygiene. All the information was collected in class under the supervision of trained research assistants in the absence of the teachers. Students' menstrual knowledge score was calculated out of the 7 knowledge specific questions. Each correct response earned one point, whereas any wrong response attracted no mark. Good knowledge of menstruation and menstrual hygiene was given to those respondents who scored greater than or equal to the mean, and poor knowledge of menstruation and menstrual hygiene was given to those respondents who scored below the mean score. Students' practice of menstrual hygiene score was calculated out of the practice specific questions. Each correct response earned one point, whereas any wrong response attracted no mark. Good practice of menstrual hygiene was given to those respondents who scored above mean score and poor practice of menstrual hygiene were given to those respondents who scored below mean score.

The instrument was pretested among 50 students from a secondary school different from the ones that were used for the main study. The exercise helped in assessing the appropriateness of the questions in eliciting desired responses.

Permission of the study was obtained from school authorities of the respective schools used for the study. Informed consents (written) was obtained from the parents and assents from the participants. Participation was entirely voluntary and confidentiality was ensured; codes rather than participants' names were used as personal identifiers and were stored in a computer that was only accessible to the principal investigator.

\section{Statistical analysis}

After data collection, each questionnaire was given a unique code and entered into SPSS version 20. Frequencies of variables were used to check for missed values and outliers. Any error identified at this time was corrected after revision of the original data using the code numbers. Descriptive analysis was used, among others, for the socio-demographic characterization of the respondents and other relevant variables (age, sex, education, marital status etc). Chi-square test was used to compare for possible significant differences between knowledge and practice of menstrual hygiene and selected categorical variables. For all statistical analysis, a $\mathrm{P}$ value less than 0.05 was considered significant.

\section{RESULTS}

\section{Socio-demographic characteristics of respondents}

Four hundred and forty-seven respondents participated in the study, making a response rate of $100 \%$. The majority of the respondents $266(59.51 \%)$ are in the age group 1416years. The mean age of the study participants was 14.7 years $(\mathrm{SD} \pm 1.4$ years) and mean age at menarche was 12.5 years. One hundred and eighty respondents are in SS1.
More than half of the respondents 252 (56.38\%) were Christians and three hundred and nineteen $(71.36 \%)$ are Yorubas. The majority of the respondent's parents' had the secondary and tertiary level of education.

\section{Table 1: Sociodemographic characteristics} of respondents.

\begin{tabular}{|c|c|c|}
\hline Variables & Frequency $(n=447)$ & Percent \\
\hline \multicolumn{3}{|l|}{ Age } \\
\hline $10-13$ & 57 & 12.75 \\
\hline $14-16$ & 266 & 59.51 \\
\hline $17-19$ & 124 & 27.74 \\
\hline \multicolumn{3}{|l|}{ Class } \\
\hline JSS 1 & 70 & 15.65 \\
\hline JSS 2 & 40 & 8.94 \\
\hline JSS 3 & 80 & 17.89 \\
\hline SS 1 & 180 & 40.27 \\
\hline SS 2 & 77 & 17.23 \\
\hline \multicolumn{3}{|l|}{ Religion } \\
\hline Christian & 252 & 56.38 \\
\hline Muslim & 180 & 40.27 \\
\hline Traditional & 15 & 3.36 \\
\hline \multicolumn{3}{|c|}{ Ethnic group } \\
\hline Yoruba & 319 & 71.36 \\
\hline Igbo & 30 & 6.71 \\
\hline Hausa & 98 & 21.92 \\
\hline \multicolumn{3}{|c|}{ Father's level of education } \\
\hline None & 12 & 2.68 \\
\hline Primary & 56 & 12.53 \\
\hline Secondary & 200 & 44.74 \\
\hline Tertiary & 179 & 40.04 \\
\hline \multicolumn{3}{|c|}{ Mother's level of education } \\
\hline None & 16 & 3.58 \\
\hline Primary & 72 & 16.11 \\
\hline Secondary & 220 & 49.22 \\
\hline Tertiary & 139 & 31.1 \\
\hline
\end{tabular}

\section{Knowledge of respondents on menstruation and menstrual hygiene}

The majority of the respondents $(96.42 \%)$ had heard about menarche before menstruation and the main source of information was the respondents' mothers $(41.83 \%)$. More than half of the respondents describe menstruation as a pathological process. About $38.93 \%$ said it is caused by hormones.

Above forty percent of the respondents said the source of menstrual blood is the vaginal while only $22.37 \%$ said it is from the uterus. More than half of the respondents said the normal menstrual cycle length is greater than 35 days. Overall more than half $(55.92 \%)$ of the respondents had good knowledge of menstruation and menstrual hygiene.

\section{Attitude on menstruation and menstrual hygiene}

About $64 \%$ of the respondents describe their response to their first menses as scary, discomforting or emotionally 
disturbing. Majority of the respondents $73.83 \%$ had menstrual symptoms. Abdominal pains and anorexia were the major symptoms experienced during menstruation among the respondents. More than $80 \%$ of the respondents attended school during their menstruation.

Table 2: Knowledge of respondents on menstruation.

\begin{tabular}{|c|c|c|}
\hline Variables & Frequency & Percent \\
\hline \multicolumn{3}{|l|}{ What is menstruation } \\
\hline Physiological process & 180 & 40.27 \\
\hline Pathological process & 261 & 58.39 \\
\hline Don't know & 10 & 2.24 \\
\hline \multicolumn{3}{|c|}{ Causes of menstruation } \\
\hline Hormones & 174 & 38.93 \\
\hline Curse of God & 30 & 6.71 \\
\hline Caused by disease & 243 & 54.36 \\
\hline \multicolumn{3}{|c|}{ Source of menstrual blood } \\
\hline Uterus & 100 & 22.37 \\
\hline Vaginal & 200 & 44.74 \\
\hline Bladder & 80 & 17.89 \\
\hline Abdomen & 67 & 14.98 \\
\hline \multicolumn{3}{|l|}{ Normal cycle length } \\
\hline 21-35days & 191 & 42.73 \\
\hline$>35$ days & 256 & 57.27 \\
\hline \multicolumn{3}{|c|}{ Ever heard about menstrual before menarche } \\
\hline Yes & 431 & 96.42 \\
\hline No & 16 & 3.58 \\
\hline \multicolumn{3}{|l|}{ *Source of information } \\
\hline Mother & 187 & 41.83 \\
\hline Teacher & 135 & 30.20 \\
\hline Friends & 145 & 32.44 \\
\hline Books & 32 & 7.16 \\
\hline Media (TV, Radio) & 15 & 3.36 \\
\hline \multicolumn{3}{|l|}{ Knowledge Score } \\
\hline Good & 250 & 55.92 \\
\hline Poor & 197 & 44.07 \\
\hline
\end{tabular}

A few were absent from school during their menstruation. The reasons for absent from school were mainly lack of water in school and lack of disposal facilities $56.25 \%$ and $42.5 \%$ respectively. Majority of the respondents did not experience restriction during their menses. Major types of restriction experience were avoidance of celebration, festivities and prayers.

\section{Practice and hygiene during menstruation}

About forty seven percent of respondents used rag and used cloth as absorbent material during menses while only $20.36 \%$ used sanitary pad. Fifty five percent of respondents changed the absorbent material once a day during menses and $19 \%$ changed the materials three or more times. Fifty one percent of respondents changed panties once during the period of menses and only $21.25 \%$ changed it 3 or more times. Majority of the respondents $52.1 \%$ disposed the used absorbent material in the toilet while only $50 \%$ wrap the used pad before disposing it. Majority of the respondents did not clean their genitalia during the period of menstruation. Overall $74.72 \%$ of the respondents had poor practice while only $25 \%$ had good practice.

Table 3: Attitude on menstruation and menstrual hygiene.

\begin{tabular}{|c|c|c|}
\hline Variables & Frequency & Percent \\
\hline \multicolumn{3}{|l|}{ Reaction to first menses } \\
\hline Happy & 160 & 35.79 \\
\hline Scared & 170 & 38.03 \\
\hline Discomfort & 88 & 19.69 \\
\hline Emotional Disturbance & 29 & 6.49 \\
\hline \multicolumn{3}{|c|}{ Presence of menstrual symptoms } \\
\hline Yes & 330 & 73.83 \\
\hline No & 117 & 26.16 \\
\hline \multicolumn{3}{|c|}{ Do you attend school during menses } \\
\hline Yes & 367 & 82.10 \\
\hline No & 80 & 17.89 \\
\hline \multicolumn{3}{|l|}{ *If No why } \\
\hline $\begin{array}{l}\text { Lack of toilet facilities in } \\
\text { school }\end{array}$ & 26 & 32.5 \\
\hline Fear of unexpected bleeding & 14 & 17.5 \\
\hline Lack of material or pad & 10 & 12.5 \\
\hline $\begin{array}{l}\text { Presence of menstrual } \\
\text { symptoms }\end{array}$ & 45 & 56.25 \\
\hline lack of water & 34 & 42.5 \\
\hline Lack of disposal facilities & 12 & 15.0 \\
\hline \multicolumn{3}{|c|}{ Do you experience restriction during menstruation } \\
\hline Yes & 212 & 47.43 \\
\hline No & 235 & 52.57 \\
\hline \multicolumn{3}{|c|}{ *Types of restriction during menses } \\
\hline $\begin{array}{l}\text { Avoid celebration and } \\
\text { festivities }\end{array}$ & 97 & 45.75 \\
\hline Avoid certain food & 38 & 17.92 \\
\hline Avoid housework & 20 & 9.43 \\
\hline Avoid prayers & 80 & 37.74 \\
\hline
\end{tabular}

Association between selected socio-demographic variables and knowledge of menstruation and menstrual hygiene

More adolescents in the age group 15-19 years (70\%) had good knowledge of menstruation and menstrual hygiene compared to those in age group 10-14 years $(36.9 \%)$ $\left(\chi^{2}=47.68, \mathrm{P}=0.001\right)$.

Sixty four percent of adolescents whose mothers had greater than secondary school education had good knowledge of menstruation and menstrual hygiene compared to those whose mother had less than secondary school education $\left(\chi^{2}=42.52, \mathrm{P}=0.001\right)$.

Respondents living with both parents had good knowledge of menses and menstrual hygiene compared 
with respondents living with single parents or relatives. $\left(\chi^{2}=123.9, \mathrm{P}=0.001, \mathrm{Df}=2\right)$.

Table 4: Practice during menstruation.

\begin{tabular}{|c|c|c|}
\hline Variables & Frequency & Percent \\
\hline \multicolumn{3}{|c|}{ Type of absorbent material use during menses } \\
\hline Sanitary pad & 91 & 20.36 \\
\hline Rag/used cloth & 209 & 46.76 \\
\hline Toilet roll & 147 & 32.89 \\
\hline \multicolumn{3}{|c|}{$\begin{array}{l}\text { Frequency of changing absorbent material during } \\
\text { menses }\end{array}$} \\
\hline Once & 247 & 55.26 \\
\hline Twice & 115 & 25.73 \\
\hline Three or more times & 85 & 19.02 \\
\hline \multicolumn{3}{|c|}{ Frequency of changing panties during menses } \\
\hline Once & 227 & 50.78 \\
\hline Twice & 125 & 27.96 \\
\hline Three or more times & 95 & 21.25 \\
\hline \multicolumn{3}{|c|}{ Method of disposing of used pad } \\
\hline Dust bin & 103 & 43.27 \\
\hline Drain & 9 & 3.78 \\
\hline Toilet & 124 & 52.10 \\
\hline Open field & 2 & 0.84 \\
\hline \multicolumn{3}{|c|}{ Types of pad wrap use for disposing of pad } \\
\hline Papers & 46 & 19.33 \\
\hline Plastic bag & 74 & 31.09 \\
\hline Not wrap & 118 & 49.58 \\
\hline \multicolumn{3}{|c|}{ Do you clean your genitalia during menstruation? } \\
\hline Yes & 199 & 44.52 \\
\hline No & 248 & 55.48 \\
\hline \multicolumn{3}{|l|}{ Practice } \\
\hline Good & 113 & 25.28 \\
\hline Poor & 334 & 74.72 \\
\hline
\end{tabular}

Table 5: Association between selected sociodemographic variables and knowledge of menstrual hygiene.

\begin{tabular}{|c|c|c|c|}
\hline Variables & $\begin{array}{l}\text { Good(250) } \\
\text { Yes }\end{array}$ & $\begin{array}{l}\text { Poor(197) } \\
\text { Yes }\end{array}$ & $\begin{array}{l}\text { Statistical } \\
\text { Indices }\end{array}$ \\
\hline \multicolumn{4}{|l|}{ Age group } \\
\hline $10-14(192)$ & $71(36.9)$ & $121(63.1)$ & \multirow{2}{*}{$\begin{array}{l}\chi^{2}=47.68 \\
P=0.000\end{array}$} \\
\hline $15-19(255)$ & $179(70)$ & $76(30)$ & \\
\hline \multicolumn{4}{|c|}{ Mothers Education } \\
\hline $\begin{array}{l}\geq \text { Secondary } \\
\text { School }(359)\end{array}$ & $228(63.5)$ & $131(36.4)$ & \multirow{2}{*}{$\begin{array}{l}\chi^{2}=42.52 \\
P=0.000\end{array}$} \\
\hline $\begin{array}{l}<\text { Secondary } \\
\text { School }(88)\end{array}$ & $22(25.0)$ & $66(75.0)$ & \\
\hline \multicolumn{4}{|c|}{ Fathers Education } \\
\hline $\begin{array}{l}\geq \text { Secondary } \\
\text { School }(379)\end{array}$ & $223(58.8)$ & $156(41.2)$ & \multirow{2}{*}{$\begin{array}{l}\chi^{2}=8.56 \\
P=0.003\end{array}$} \\
\hline $\begin{array}{l}<\text { Secondary } \\
\text { School }(68)\end{array}$ & 27(39.7) & $41(60.3)$ & \\
\hline \multicolumn{4}{|c|}{ Person living with Parents (171) } \\
\hline Single(171) & $151(88.3)$ & $20(11.7)$ & \multirow{3}{*}{$\begin{array}{l}\mathrm{Df}=2 \\
\mathrm{P}=0.000 \\
\chi^{2}=123.9\end{array}$} \\
\hline Parents(191) & $78(40.84)$ & $113(59.16)$ & \\
\hline Relatives(85) & $21(24.71)$ & $64(75.29)$ & \\
\hline
\end{tabular}

\section{Association between selected variables and practice of menstrual hygiene}

There is no statistically significant association between the age of adolescent and good practice of menstrual hygiene $\left(\chi^{2}=3.52, \mathrm{P}=0.061\right)$. There was a statistically significant association between good practice of menstrual hygiene and living with parents $\left(\mathrm{P}=0.008, \chi^{2}=\right.$ 6.959). There is no statistically significant association between school attendance during menses and practice of menstrual hygiene $\left(\chi^{2}=1.149, \mathrm{P}=0.284\right)$.

Table 6: Association between selected variables and practice of menstrual hygiene.

\begin{tabular}{|c|c|c|c|}
\hline Variables & $\begin{array}{l}\text { Good (113) } \\
\text { Yes }\end{array}$ & $\begin{array}{l}\text { Poor }(334) \\
\text { Yes }\end{array}$ & $\begin{array}{l}\text { Statistical } \\
\text { Indices }\end{array}$ \\
\hline \multicolumn{4}{|l|}{ Age group } \\
\hline $10-14(192)$ & $40(20.83)$ & $152(79.17)$ & \multirow{2}{*}{$\begin{array}{l}\chi^{2}=3.52 \\
P=0.061\end{array}$} \\
\hline $15-19(255)$ & $73(28.63)$ & $182(71.37)$ & \\
\hline \multicolumn{3}{|c|}{ Person living with } & \multirow{3}{*}{$\begin{array}{l}P=0.008 \\
\chi^{2}=6.959\end{array}$} \\
\hline Parents(362) & $82(22.70)$ & $280(77.30)$ & \\
\hline Relatives (85) & $31(36.47)$ & $54(63.53)$ & \\
\hline \multicolumn{3}{|c|}{ School attendance during menses } & \multirow{3}{*}{$\begin{array}{l}\chi^{2}=1.149 \\
\mathrm{P}=0.284\end{array}$} \\
\hline Yes(367) & $89(24.25)$ & $278(75.75)$ & \\
\hline $\operatorname{No}(80)$ & $24(30.00)$ & $56(70.00)$ & \\
\hline
\end{tabular}

\section{DISCUSSION}

Menstruation is an important pubertal development. A lot of misconceptions about this process translated into poor knowledge and hygienic practices on menstruation. Adequate knowledge on menstruation and its hygienic practices will prevent reproductive ill-health. This study revealed high level of awareness on menarche and the main source of information were the respondents mother, this was similar to the findings of a study done in Kano, but contrary to the findings of a study done in Egypt by El-Gilany et al that revealed that the main source of information was mass media. ${ }^{21,22}$ The reason for this might be due to the fact that most of the respondents mothers are educated in this study. Also, in Yoruba culture, children are usually closer to their mothers. In this study a little above half of the respondents have good knowledge on menstruation and its hygienic practices which was similar to the findings of studies carried out in Ile-ife and Banglandesh that revealed the baseline good knowledge on menstrual hygiene and its practices to be $51.2 \%$ before intervention. ${ }^{23,24}$ This was contrary to the findings of a study carried out in Kano by Lawan that shows that only $4 \%$ of respondents have good knowledge of menstruation and its hygienic practices. ${ }^{21}$ This might be due to the fact that the study grouped knowledge into fair, good and poor. In this study majority of respondents were either scared or emotionally disturbed at their first menses. This was similar to findings of a study carried out in Karach Pakistan by Ali et al and in Indian by Tiwari et al. ${ }^{25,26}$ The findings in this study might be due to the fact that they are not given adequate information and not properly prepared for the process. Menstrual 
hygiene practices are important to ensure prevention of diseases among adolescents. The use of reusable materials during menstruation increases the risk of infection if not properly cleaned and dried. Findings in this study revealed that majority of respondents in this study use clothes/rag and toilet roll during menses. This was similar to findings of a study conducted by AbioyeKuteyi and Adinma et al in Onitsha Nigeria that revealed that unsanitary absorbent materials were used during menses. ${ }^{27,9}$ This findings might be due to high level of poverty in this environment as majority of the respondents' parents and guidians were not gainfully employed. Good menstrual hygiene practice include safe and sanitary disposal of absorbent materials used during menses. In this study majority of respondents disposed the absorbent material without wrapping it and disposed it in the toilet. This contrary to the findings of Madhusudan $\mathrm{M}$ et al, Dasgupta et al, Mudey et al and Tharkre et al whose findings were that majority of their respondents burn or wrap the absorbent materials used during menses and disposed of it in place used for solid waste disposal. ${ }^{12,28-30}$ The practice of not wrapping the absorbent materials and disposing it in the toilet is unsightly and can lead to breeding place for insects and vermites. This should be discouraged. Overall the hygienic practice during menstruation was poor as only $25 \%$ of respondents observed good hygienic practice. The finding of this study was lower than studies conducted in Ethiopia and North western Nigeria which were $90.9 \%$ and $88.7 \%$, respectively. ${ }^{21,31}$ This implies that not all respondents that had good knowledge of menstruation and menstrual hygiene practiced it. There was positive association between parents' level of education and good knowledge of menstruation and menstrual hygiene in this study. Mothers who are educated are likely to talk to their children about menstruation compared to mothers who were not. A positive association was also observed between good hygienic practice and living with parents. It might be that adolescent who live with their parents were better monitored and guided during their menstrual period compared to those who reside with relatives as those adolescents may receive less attention and care. Also, those who live with relatives might not discuss openly about menstruation and/or relatives might not buy sanitary napkins and thus they might be less likely to use sanitary napkins. In this study restrictions were practiced by close to half of the respondents girls and this was mostly to avoid celebration and festivities. This was similar to the findings of the study done in the past by Thakre et al and Mudey. ${ }^{30,31}$

Findings from this study should be interpreted in the light of some limitations. First, it is a crossectional study and this may limit causal conclusion. In addition, the study relied on self reported information on menstruation and menstrual hygiene, which is subject to bias. Nevertheless, our findings have significant implications for adolescent sexual and reproductive interventions in Nigeria.

\section{CONCLUSION}

The study concluded that majority of the adolescents do not observe good hygienic practice during menstruation despite relatively good knowledge of menstruation and menstrual hygiene. Efforts have to be put into ensuring that adolescent are well educated on meaning of menstruation, importance of good hygienic practice both in schools and at home. It is also very important that both parents provide support during the period of menses as it showed in this study that there is an association between respondents residing with parents and hygienic practice during menses.

\section{Funding: No funding sources}

Conflict of interest: None declared

Ethical approval: The study was approved by the Institutional Ethics Committee of the Bowen University Teaching Hospital, Ogbomoso

\section{REFERENCES}

1. Sommer M, Sahin M. Overcoming the taboo: advancing the global agenda for menstrual hygiene management for schoolgirls. Am J Public Health. 2013;103:1556-9.

2. Ten VA. Menstrual hygiene: A neglected condition for the achievement of several millennium development goals, European Commission-Europe Aid; 2007.

3. Puberty education and menstrual hygiene Management. Published in 2014 by the United Nations Educational, Scientific and Cultural Organization 7, place de Fontenoy, 75352 Paris 07 SP, France (http://creativecommons.org/licenses/bysa/3.0/ ISBN 978-92-3-100011-9.

4. Neginhal VS. Knowledge, attitude and practices of menstrual hygiene among secondary school girls in Semi Urban Area, Belgaum District: A cross sectional study, Master of Public Health thesis, KLE University; 2010.

5. Jothy K, Kalaiselv IS. Is menstrual hygiene and management an issue for the rural adolescent school girls? Elixir Int J. 2012;44:7223-8.

6. McMahon SA, Winch PJ, Caruso BA, Obure AF, Ogutu EA, Ochari IA et al. The girl with her period is the one to hang herhead: reflections on menstrual management among schoolgirls in rural Kenya. BMC Int Health Hum Rights. 2011;11(7):1-10.

7. Risi L. Parents ignoring sex education, 2000. http://news.bbc.co.uk/2/hi/health/988353.stm (Accessed 5 December 2013).

8. Goldman J. Responding to parental objections to school sexuality education: A selection of 12 objections. Sex Education. 2008;8:415-38.

9. Adinma ED, Adinma JI. Perceptions and practices on menstruation amongst Nigerian secondary school girls. Afr J Reprod Health. 2008;12:74-83.

10. Aniebue UU, Aniebue PN, Nwankwo TO. The impact of pre-menarcheal training on menstrual 
practices and hygiene of Nigerian school girls. Pan Afr Med J. 2009;2:9.

11. Das P, Baker KK, Dutta A, Swain T, Sahoo S, Das BS et al. Menstrual Hygiene Practices, WASH Access and the Risk of Urogenital Infection in Women from Odisha, India. PLoS One. 2015;10(6):e0130777.

12. Dasgupta A, Sarkar M. Menstrual hygiene: How hygienic is the adolescent girl? Indian J Community Med. 2008;33(2):77-80.

13. Baisley K, Changalucha J, Weiss HA, Mugeye K, Everett D, Hambleton I et al. Bacterial vaginosis in female facility workers in north-western Tanzania: prevalence and risk factors. Sex Transm Infect. 2009;85:370-5.

14. Aniebue UU, Aniebue PN, Nwankwo TO. The impact of pre-menarcheal training on menstrual practices and hygiene of Nigerian school girls. Pan Afr Med J. 2009;2:9.

15. Zegeye DT, Megabiaw B, Mulu A. Age at menarche and the menstrual pattern of secondary school adolescents in northwest Ethiopia. BMC Women's Health. 2009;9:29.

16. Sarah H, Thérèse M. Sue: a resource for improving menstrual hygiene around the world. Water Aid. 2012;22-43.

17. Annabel S, Abebaw F, Worku A, Woldemariam G, Helen A, Behailu $G$ et al. Ethiopia young adult survey: A study in seven regions. Addis Ababa, Ethiopia: Population Council; 2010. Available from http://itacaddis.org/docs/2013_09_24_08_12_15_Eth iopianYoungAdultSurvey2010.pdf

18. Oyo State TESCOM. Oyo state post-primary school teaching service commission. Available from http://oyotescom.org/oyotescom/schools.php. Accessed on 26th August; 2016.

19. Ibrahim T. A Research methodology and dissertation writing for health and allied health professionals. First ed. Abuja: cress Global link Limited; 2009.

20. Upashe SP, Tekelab T, Mekonne J. Assesement of knowledge and practice of menstrual hygiene among high school girls in Western Ethiopia. BMC Women's Health; 2015;15:84.

21. Lawan UM, Nafisa Wali Yusuf, Aisha Bala Musa Menstruation and Menstrual Hygiene amongst Adolescent School Girls in Kano, Northwestern Nigeria Afr J Reprod Health. 2010;14(3):201-8.

22. El-Gilany AH, Badawik K, El-fedawy S. Menstrual Hygiene among Adolescent School girls in
Mansoura, Egypt. Reproductive Health Matters. 2005;13(26):147-52.

23. Olabanjo OO, Olorunfemi AO, Phillips A, Temitope OO. Knowledge, practices and socio-cultural restrictions associated with menstruation and menstrual hygiene among in-school adolescents in Ile-Ife, Nigeria. ijprm. 2014;16.

24. Haque SE, Rahman, Itusko K, Mutahara M, Sakisaka K. The effect of a school-based educational intervention on menstrual health: an intervention study among adolescent girls in Bangladesh. BMJ 2014:e004607.

25. Ali TS, Rizvi SN. Menstrual Knowledge and Practices of Female adolescents in Urban Karachi,Pakistan. J Adolescence. 2010;33(4):531-41.

26. Tiwari H, Oza UN, Tiwari R. Knowledge, attitudes and beliefs about menarche of adolescent girls in Anand district, Gujarat. East Mediterr Health J. 2006;12(3-4):428-33.

27. Abioye-Kuteyi E. Menstrual knowlegde and practices amongst secondary school girls in IleIfe,Nigeria. The $\mathbf{J}$ Royal Soc Prom Health. 2000;120(1):23.

28. Madhusudan M, Mahadeva TS. Menstrual hygiene: knowledge and practice among secondary school girls of Hosakote, rural Bangalore. Int J Basic Appl Medic Sci. 2014;4(2):313-20.

29. Mudey AB, Keshwani N, Mudey GA, Goyal RC. A Cross-sectional study on the awareness regarding safe and hygienic practices amongst school going adolescent girls in the rural areas of Wardha District. Global J Health Sci. 2010;2(2):225-31.

30. Tharkre S, Reddy M, Rathi N, Pathak K, Ughade S. Menstrual hygiene: knowledge and practice among adolescent school girls of Saoner, Nagpur District. J Clinic Diagnos Res .2011;5:1027-33.

31. Teklemariam G. Practice of menstrual hygiene and associated factors among female Mehalmeda high school students in Amhara Regional State, Ethiopia. Sci J Public Health. 2014;2(3):189-95.

Cite this article as: Fehintola FO, Fehintola AO, Idowu A, Aremu AO, Ogunlaja OA, Ogunlaja IP. Assessment of knowledge, attitude and practice about menstruation and menstrual hygiene among secondary high school girls in Ogbomoso, Oyo state, Nigeria. Int J Reprod Contracept Obstet Gynecol 2017;6:1726-32. 